\title{
Kemampuan Pemecahan Masalah Matematika Ditinjau dari Kreativitas dan Kecerdasan Emosional
}

\author{
L K Ariati ${ }^{1, a)}$ dan Leny Hartati $^{1}$ \\ Program Studi Pendidikan Matematika Universitas Indraprasta PGRI \\ aE-mail: lizakhoirunisaariati@gmail.com
}

Dikirim: 06 September 2017 ; Diterima: 08 November 2017; Dipublikasikan: 20 Desember 2017

\begin{abstract}
Abstrak. Penelitian ini bertujuan untuk mengetahui: 1) pengaruh kreativitas dan kecerdasan emosional terhadap kemampuan pemecahan masalah matematika; 2) pengaruh kreativitas terhadap kemampuan pemecahan masalah matematika; 3) pengaruh kecerdasan emosional terhadap kemampuan pemecahan masalah matematika. Metode penelitian yang digunakan adalah survei korelasional dengan teknik analisis data yaitu korelasi dan regresi ganda. Populasi dalam penelitian ini sebanyak 136 siswa. Sampel dalam penelitian ini berjumlah 58 siswa dengan teknik pengambilan simpel random sampling. Instrumen yang digunakan dalam penelitian ini adalah instrumen angket, untuk mengukur kreativitas dan kecerdasan emosional serta instrumen tes untuk mengukur kemampuan pemecahan masalah matematika. Hasil penelitian dapat disimpulkan, yaitu : pertama, terdapat pengaruh signifikan kreativitas dan kecerdasan emosional secara bersama-sama terhadap kemampuan pemecahan masalah matematika; kedua, terdapat pengaruh yang signifikan kreativitas terhadap kemampuan pemecahan masalah matematika; ketiga, terdapat pengaruh yang signifikan kecerdasan emosional terhadap kemampuan pemecahan masalah matematika.
\end{abstract}

Kata kunci: Kreativitas, Kecerdasan Emosional, Kemampuan Pemecahan Masalah Matematika

\section{Pendahuluan}

Salah satu tujuan umum pembelajaran matematika adalah agar siswa memiliki kemampuan pemecahan masalah yang meliputi kemampuan memahami masalah, merancang model matematika, menyelesaikan model dan menafsirkan solusi yang diperoleh (Hasbullah dan Wiratomo, 2015:36). Namun, berdasarkan hasil studi pendahuluan yang dilakukan, ditemukan bahwa kemampuan pemecahan masalah matematika siswa masih tergolong rendah. Salah satu faktor penyebabnya adalah siswa kurang memahami soal yang berbentuk aplikasi karena memerlukan kemampuan berpikir tingkat tinggi untuk menganalisanya. Selain itu siswa terbiasa menggunakan rumus dan contoh soal yang 
diberikan oleh guru. Jika mengalami kesulitan, siswa cenderung malas, mudah menyerah untuk mengerjakan soal tersebut tanpa adanya usaha untuk bertanya atau mencari penyelesaian dari sumber referensi lain. Hal ini perlu adanya motivasi dari diri siswa untuk mau belajar dan merasa tertantang untuk mengerjakan soal motivasi mempengaruhi hasil belajar siswa (Lestari, 2017:83).

Pemecahan masalah matematika pada umumnya lebih identik dengan soal-soal yang berbentuk uraian. Hal ini dikarenakan soal yang berbentuk uraian membutuhkan tahapan pemecahan yang bertahap sehingga kesimpulan yang didapatkan jelas dan sistematis. Pentingnya kemampuan pemecahan masalah oleh siswa dalam matematika ditegaskan juga oleh Hakim (Sianipar dan Roida, 2015: 168), yaitu "suatu proses untuk peserta didik dimungkinkan memperoleh pengalaman menggunakan pengetahuan serta keterampilan yang sudah dimilikinya untuk diterapkan dalam menyelesaikan soal-soal berbentuk masalah atau soal-soal aplikasi dalam pelajaran matematika." Polya (Mawaddah dan Hana, 2015: 167) menambahkan empat langkah untuk memecahkan masalah matematika, yaitu (1) mampu memahami masalah; mampu membuat rencana menyelesaikan masalah; (3) mampu melaksanakan rencana pemecahan masalah; (4) mampu memeriksa kembali.

Faktor yang mempengaruhi kemampuan pemecahan masalah matematika antara lain adalah kreativitas dan kecerdasan emosional. Kreativitas memiliki peran penting dalam kegiatan pembelajaran karena siswa di tuntut dapat memahami dan mengembangkan pengetahuan serta konsep materi yang sedang dipelajari termasuk dalam hal menyelesaikan masalah matematika. Barron (Hosnan, 2016: 245) menyatakan "kreativitas adalah kemampuan untuk menciptakan sesuatu yang baru atau kombinasi dari unsur-unsur yang telah ada sebelumnya". Selanjutnya Munandar (Isvina, dkk, 2015: 2) membagi kreativitas ke dalam beberapa aspek, yaitu: aspek kelancaran, aspek fleksibilitas, aspek orisinalitas, dan aspek elaborasi. Keempat aspek tersebut memiliki keterkaitan satu sama lain. Jika salah satu aspek mengalami ketergangguan dari luar maupun dalam mengakibatkan aspek lain pun terpengaruhi.

Kegiatan belajar siswa tidak hanya sebagai proses berpikir tetapi juga melibatkan emosi. Setiap emosi memotivasi siswa dengan cara positif dan negatif, sehingga dapat mempengaruhi kepribadian dan pada akhirnya mempengaruhi kemampuan 
Kemampuan Pemecahan Masalah Matematika Ditinjau dari Kreativitas dan Kecerdasan Emosional

belajar dan kemampuan dalam memecahkan masalah. Emosi yang positif akan mempengaruhi siswa untuk berkonsentrasi terhadap aktivitas belajar. Untuk itu, siswa perlu memiliki kecerdasan emosional agar dapat mengelola emosi tersebut dengan baik ketika emosi itu timbul. Mubayidh (2006:7) mengatakan bahwa kecerdasan emosional adalah kemampuan untuk menyikapi pengetahuan-pengetahuan emosional dalam bentuk menerima, memahami, dan mengelolanya. Selanjutnya Salovey (Goleman, 2015: 56-57) mengemukakan bahwa kecerdasan emosioanl memiliki empat aspek yaitu: (1) mengenali emosi sendiri, (2) kemampuan mengelola emosi, (3) memotivasi diri sendiri, (4) mengendali emosi orang lain.

Kreativitas dan kecerdasan emosional yang kompleks ini menarik untuk dikaji dan coba diterapkan pada pemecahan masalah matematika, karena kemampuan pemecahan masalah matematika yang dicapai di SMA Widya Nusantara Bekasi masih belum maksimal. Dengan demikian, penulis ingin mengetahui kemampuan pemecahan masalah matematika ditinjau dari kreativitas dan kecerdasan emosional.

\section{Metodologi Penelitian}

Penelitian ini dilakukan di SMA Widya Nusantara Bekasi. Metode yang dilakukan dalam penelitian ini adalah metode survei korelasional dengan teknik analisis data yaitu korelasi dan regresi ganda. Instrumen yang digunakan dalam penelitian ini adalah instrumen angket, untuk mengukur kreativitas dan kecerdasan emosional serta instrumen tes untuk mengukur kemampuan pemecahan masalah matematika. Perhitungan untuk uji hipotesis menggunakan bantuan SPSS 17.0 yang terlebih dahulu dilakukan uji persyaratan analisis data, yaitu uji normalitas, linieritas dan multikolinearitas. Adapun desain penelitian sebagai berikut.

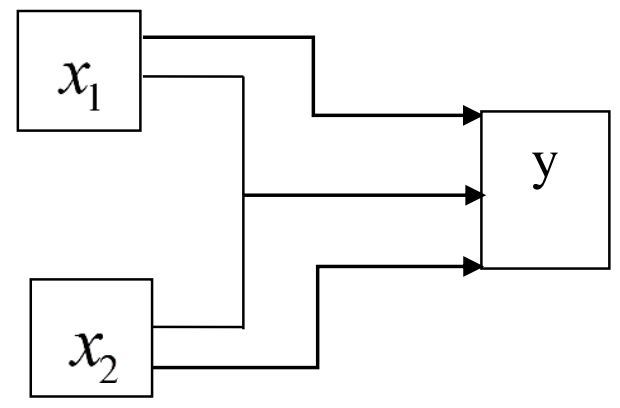

Keterangan :

X1 : Kreativitas

X2 : Kecerdasan Emosional

Y : Kemampuan Pemecahan

Masalah Matematika

Sampel dalam penelitian ini sebanyak 58 siswa dari populasi yang berjumlah 136 siswa. Pengambilan jumlah sampel menggunakan rumus Isaac dan Michael (Arikunto, 2013: 179) sebagai berikut : 


$$
S=\frac{\chi^{2} N P(1-P)}{d^{2}(N-1)+\chi^{2} P(1-P)}
$$

Keterangan:

$\mathrm{S} \quad=$ ukuran sampel,

$\mathrm{N}=$ ukuran populasi,

$\mathrm{P} \quad=$ proporsi dalam populasi,

$\mathrm{d}=$ ketelitian (error),

$\chi^{2}=$ harga tabel Chi-Kuadrat untuk $\alpha$ tertentu.

\section{Hasil dan Pembahasan}

Berdasarkan penelitian yang telah dilakukan di SMA Widya Nusantara Bekasi diperoleh hasil penelitian sebagai berikut:

Tabel 1. Hasil Perhitungan Statistik Deskriptif

\begin{tabular}{|c|c|c|c|c|}
\hline \multicolumn{5}{|c|}{ Statistics } \\
\hline & & Kreativitas & $\begin{array}{c}\text { Kecerdasan } \\
\text { Emosional }\end{array}$ & $\begin{array}{c}\text { Kemampuan } \\
\text { Pemecahan Masalah } \\
\text { Matematika }\end{array}$ \\
\hline \multirow[t]{2}{*}{$\mathrm{N}$} & Valid & 58 & 58 & 58 \\
\hline & Missing & 0 & 0 & 0 \\
\hline \multicolumn{2}{|c|}{ Mean } & 87.33 & 98.12 & 70.76 \\
\hline \multicolumn{2}{|c|}{ Median } & 88.00 & 98.50 & 73.00 \\
\hline \multicolumn{2}{|c|}{ Mode } & $84^{\mathrm{a}}$ & $77^{\mathrm{a}}$ & 77 \\
\hline \multicolumn{2}{|c|}{ Std. Deviation } & 9.893 & 12.437 & 7.284 \\
\hline \multicolumn{2}{|c|}{ Variance } & 97.873 & 154.669 & 53.064 \\
\hline \multicolumn{2}{|c|}{ Range } & 48 & 48 & 36 \\
\hline \multicolumn{2}{|c|}{ Minimum } & 64 & 76 & 45 \\
\hline \multicolumn{2}{|c|}{ Maximum } & 112 & 124 & 81 \\
\hline \multicolumn{2}{|c|}{ Sum } & 5065 & 5691 & 4104 \\
\hline
\end{tabular}

Pengujian Persyaratan Analisis Data

Tabel 2. Hasil Uji Normalitas

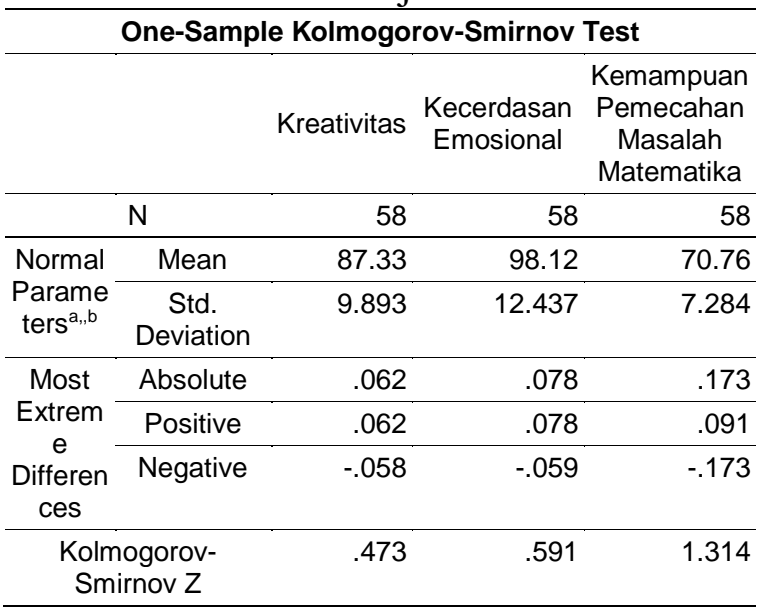

\begin{tabular}{cccc}
$\begin{array}{c}\text { Asymp. Sig. (2- } \\
\text { tailed) }\end{array}$ & .979 & .876 & .063 \\
\hline
\end{tabular}

Dari tabel diperoleh kesimpulan bahwa nilai sig untuk seluruh kelompok memiliki nilai sig > $>0,05$, sehingga dapat disimpulkan bahwa data berdistribusi normal.

Tabel 3. Hasil Uji Linieritas Kreativitas terhadap Kemampuan Pemecahan Masalah Matematika

\begin{tabular}{|c|c|c|c|c|c|c|c|}
\hline \multicolumn{8}{|c|}{ ANOVA Table } \\
\hline & & & $\begin{array}{l}\text { Sum of } \\
\text { Squares }\end{array}$ & df & $\begin{array}{l}\text { Mean } \\
\text { Square }\end{array}$ & $\mathrm{F}$ & Sig. \\
\hline \multirow{5}{*}{$\begin{array}{l}\text { Kem. } \\
\text { Pem. } \\
\text { Mslh } \\
\text { Mtk * } \\
\text { Kreativi } \\
\text { tas }\end{array}$} & \multirow{3}{*}{$\begin{array}{c}\text { Between } \\
\text { Groups }\end{array}$} & (Combined) & 2221.521 & 32 & 69.423 & 2.161 & .025 \\
\hline & & Linearity & 1167.029 & 1 & 1167.029 & 36.329 & .000 \\
\hline & & $\begin{array}{l}\text { Deviation } \\
\text { from } \\
\text { Linearity }\end{array}$ & 1054.492 & 31 & 34.016 & 1.059 & .446 \\
\hline & \multicolumn{2}{|c|}{ Within Groups } & 803.100 & 25 & 32.124 & & \\
\hline & \multicolumn{2}{|c|}{ Total } & 3024.621 & 57 & & & \\
\hline
\end{tabular}

Tabel 4. Hasil Uji Linieritas Kecerdasan Emosional terhadap Kemampuan Pemecahan Masalah Matematika

\begin{tabular}{|c|c|c|c|c|c|c|c|}
\hline \multicolumn{8}{|c|}{ ANOVA Table } \\
\hline & & & $\begin{array}{l}\text { Sum of } \\
\text { Squares }\end{array}$ & df & $\begin{array}{l}\text { Mean } \\
\text { Square }\end{array}$ & $\mathrm{F}$ & Sig. \\
\hline \multirow{5}{*}{$\begin{array}{c}\text { Kemampuan } \\
\text { Pemecahan } \\
\text { Masalah } \\
\text { Matematika } \\
\text { * Kecerdasan } \\
\text { Emosional }\end{array}$} & \multirow{3}{*}{$\begin{array}{l}\text { Between } \\
\text { Groups }\end{array}$} & (Combined) & 2000.037 & 28 & 71.430 & 2.022 & .032 \\
\hline & & Linearity & 505.324 & 1 & 505.324 & 14.303 & .001 \\
\hline & & $\begin{array}{l}\text { Deviation } \\
\text { from } \\
\text { Linearity }\end{array}$ & 1494.714 & 27 & 55.360 & 1.567 & .119 \\
\hline & \multicolumn{2}{|c|}{ Within Groups } & 1024.583 & 29 & 35.330 & & \\
\hline & \multicolumn{2}{|c|}{ Total } & 3024.621 & 57 & & & \\
\hline
\end{tabular}

Berdasarkan hasil perhitungan bahwa nilai sig varibel $\mathrm{X}_{1}$ (Kreativitas) terhadap $\mathrm{Y}$ (Kemampuan Pemecahan Masalah Matematika) dan $\mathrm{X}_{2} \quad$ (kecerdasan Emosional) terhadap Y (Kemampuan Pemecahan Masalah Matematika) $<0,05$ sehingga dapat disimpulkan data penelitian memenuhi asumsi linieritas atau hubungan antara variabel independen dan variabel dependen adalah linier.

Tabel 5. Hasil Uji Multikolinearitas Coefficients $^{a}$ 
Kemampuan Pemecahan Masalah Matematika Ditinjau dari Kreativitas dan Kecerdasan Emosional

\begin{tabular}{lcrc}
\hline & & \multicolumn{2}{c}{ Collinearity Statistics } \\
\cline { 2 - 4 } & Model & Tolerance & VIF \\
\hline 1 & Kreativitas & .737 & 1.357 \\
\cline { 2 - 4 } & Kecerdasan Emosional & .737 & 1.357 \\
\hline
\end{tabular}

a. Dependent Variable: Kemampuan Pemecahan Masalah Matematika

Dari tabel hasil uji multikolinieritas diperoleh nilai VIF $=1,188<10$ dan tolerance $=0,841$ mendekati 1 , sehingga disimpulkan bahwa tidak terdeteksi sebagai multikolinieritas (tidak terdapat hubungan kuat antara variabel bebas). Dengan demikian proses pengujian hipotesis dapat dilanjutkan.

\section{Pengujian Hipotesis}

\section{Hipotesis 1}

$$
\begin{aligned}
& H_{0}: \beta_{12}=0 \\
& H_{1}: \beta_{12} \neq 0
\end{aligned}
$$

\section{Keterangan :}

$H_{o}$ : Tidak terdapat pengaruh kreativitas dan kecerdasan emosional secara bersama-sama terhadap kemampuan pemecahan masalah matematika

$H_{1}$ : Terdapat pengaruh kreativitas dan kecerdasan emosional secara bersama-sama terhadap kemampuan pemecahan masalah matematika

\begin{tabular}{|c|c|c|c|c|c|c|}
\hline \multicolumn{7}{|c|}{ Ganda } \\
\hline & \multicolumn{6}{|c|}{ ANOVA $^{b}$} \\
\hline & Model & $\begin{array}{l}\text { Sum of } \\
\text { Squares }\end{array}$ & df & $\begin{array}{l}\text { Mean } \\
\text { Square }\end{array}$ & $\mathrm{F}$ & Sig. \\
\hline \multirow[t]{3}{*}{1} & Regression & 1200.460 & 2 & 600.230 & 18.097 & $.000^{\mathrm{a}}$ \\
\hline & Residual & 1824.161 & 55 & 33.167 & & \\
\hline & Total & 3024.621 & 57 & & & \\
\hline
\end{tabular}

Tabel 6. Hasil Uji Koefisien Regresi

\begin{tabular}{|c|c|c|c|c|c|c|}
\hline \multicolumn{7}{|c|}{ ANOVA $^{b}$} \\
\hline & Model & $\begin{array}{l}\text { Sum of } \\
\text { Squares }\end{array}$ & df & $\begin{array}{l}\text { Mean } \\
\text { Square }\end{array}$ & $\mathrm{F}$ & Sig. \\
\hline \multirow[t]{3}{*}{1} & Regression & 1200.460 & 2 & 600.230 & 18.097 & $.000^{\mathrm{a}}$ \\
\hline & Residual & 1824.161 & 55 & 33.167 & & \\
\hline & Total & 3024.621 & 57 & & & \\
\hline
\end{tabular}

a. Predictors: (Constant), Kecerdasan_Emosional, Kreativitas a. Predictors: (Constant), Kecerdasan_Emosional, Kreativitas

b. Dependent Variable: KPMM

Tabel 6 menunjukkan koefisien regresi signifikan karena diperoleh harga $\mathrm{F}_{\text {hitung }}=$ 18,097 dan nilai signifikansi $0,000<0,05$ artinya ada pengaruh positif kreativitas dan kecerdasan emosional secara bersamasama terhadap kemampuan pemecahan masalah matematika. Kemampuan pemecahan masalah matematika adalah kemampuan seseorang untuk memecahkan masalah matematika dengan menggunakan proses berpikir matematikanya yang mencakup strategi, pengetahuan, dan keterampilan yang dimiliki. Kreativitas merupakan hasil dari proses berpikir untuk menghasilkan ide baru ataupun hasil kreasi yang telah ada. Proses berpikir ini selalu mengarah pada tingkat inteligensi atau kecerdasan seseorang. Selanjutnya kecerdasan emosional adalah kemampuan seseorang mengenali emosi diri, mengelola emosi, memotivasi diri sendiri dalam membina hubungan dengan orang lain dan berhasil mengatasi tuntutan serta tekanan lingkungan. Dengan demikian, siswa yang memiliki kreativitas dan kecerdasan emosional yang tinggi, maka kemampuan 
dalam pemecahan masalah matematika juga akan tinggi.

Tabel 7. Hasil Uji Korelasi Kreativitas dan Kecerdasan Emosional Secara Simultan

Terhadap Kemampuan Pemecahan

\begin{tabular}{ccccc}
\multicolumn{5}{c}{ Masalah Matematika } \\
\hline \multicolumn{4}{c}{ Model Summary } \\
\hline Model & $\mathrm{R}$ & $\begin{array}{c}\mathrm{R} \\
\text { Square }\end{array}$ & $\begin{array}{c}\text { Adjusted } \\
\text { R Square }\end{array}$ & $\begin{array}{c}\text { Std. Error of } \\
\text { the Estimate }\end{array}$ \\
\hline 1 & $.630^{\mathrm{a}}$ & .397 & .375 & 5.759 \\
\hline a. Predictors: (Constant), Kecerdasan_Emosional, \\
Kreativitas
\end{tabular}

Dari tabel tersebut di peroleh besar hubungan kreativitas dan kecerdasan emosional (secara simultan) terhadap kemampuan pemecahan masalah matematika adalah 0,630 , hal ini menunjukkan pengaruh yang sedang. Sedangkan koefisien determinasi sebesar $39,7 \%$ menunjukkan bahwa besarnya kontribusi kreativitas dan kecerdasan emosional secara bersama-sama terhadap kemampuan pemecahan masalah matematika adalah sebesar $39,7 \%$, sisanya $(60,3 \%)$ karena pengaruh faktor lain.

Tabel 8. Uji Signifikansi Koefisien Regresi Ganda

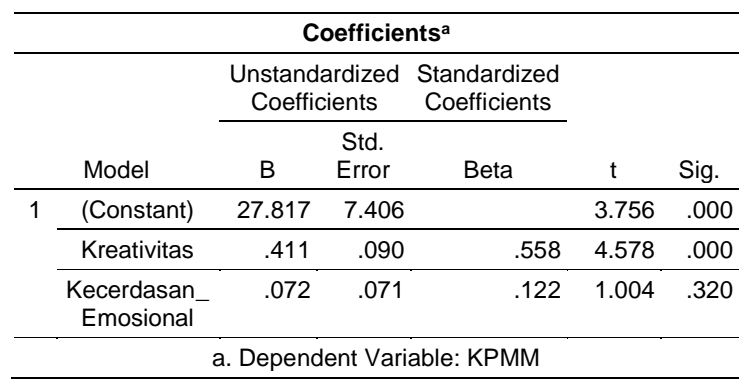

Berdasarkan tabel tersebut dapat diinterpretasikan sebagai berikut :
Konstanta sebesar 27,817; artinya jika kreativitas dan kecerdasan emosional nilainya 0 , maka kemampuan pemecahan masalah matematika nilainya adalah 27,817 .

Koefisien regresi variabel kreativitas sebesar 0,411; artinya jika variabel independen lainnya nilainya tetap dan kreativitas mengalami peningkatan 1 satuan, maka kemampuan pemecahan matematika akan mengalami peningkatan sebesar 0,411. Koefisien bernilai positif artinya terjadi hubungan positif antara kreativitas dengan kemampuan pemecahan masalah matematika. Semakin tinggi kreativitas maka semakin tinggi kemampuan pemecahan matematika.

Koefisien regresi variabel kecerdasan emosional sebesar 0,072; artinya jika variabel independen lainnya nilainya tetap dan kecerdasan emosional mengalami peningkatan 1 satuan, maka kemampuan pemecahan matematika akan mengalami peningkatan sebesar 0,072. Koefisien bernilai positif artinya terjadi hubungan positif antara kecerdasan emosional dengan kemampuan pemecahan matematika. Semakin meningkat kecerdasan emosional maka semakin meningkat kemampuan pemecahan matematika. 
Kemampuan Pemecahan Masalah Matematika Ditinjau dari Kreativitas dan Kecerdasan Emosional

\section{Hipotesis 2}

$$
\begin{aligned}
& \mathrm{H}_{0}: \beta_{1}=0 \\
& \mathrm{H}_{1}: \beta_{1} \neq 0
\end{aligned}
$$

Keterangan :

$H_{o}$ : Tidak terdapat pengaruh kreativitas terhadap kemampuan pemecahan masalah matematika

$H_{1}$ : Terdapat pengaruh kreativitas terhadap kemampuan pemecahan masalah matematika

\begin{tabular}{|c|c|c|c|c|c|c|}
\hline \multicolumn{7}{|c|}{ ANOVA $^{b}$} \\
\hline & Model & $\begin{array}{l}\text { Sum of } \\
\text { Squares }\end{array}$ & df & $\begin{array}{l}\text { Mean } \\
\text { Square }\end{array}$ & $\mathrm{F}$ & Sig. \\
\hline \multirow[t]{5}{*}{1} & Regression & 1167.029 & 1 & $\begin{array}{r}1167.0 \\
29 \\
\end{array}$ & $\begin{array}{r}35.18 \\
2\end{array}$ & $.000^{\mathrm{a}}$ \\
\hline & Residual & 1857.592 & 56 & 33.171 & & \\
\hline & Total & 3024.621 & 57 & & & \\
\hline & \multicolumn{6}{|c|}{ a. Predictors: (Constant), Kreativitas } \\
\hline & \multicolumn{6}{|c|}{ b. Dependent Variable: KPMM } \\
\hline
\end{tabular}

Tabel 9. Hasil Uji Koefisien Regresi

Tabel tersebut menunjukkan koefisien regresi signifikan karena diperoleh harga $F_{\text {hitung }}=35,182$ dan nilai signifikansi 0,000 $<0,05$ artinya ada pengaruh positif kreativitas terhadap kemampuan pemecahan masalah matematika.

Kemampuan pemecahan masalah matematika adalah kemampuan seseorang untuk memecahkan masalah matematika dengan menggunakan proses berpikir matematikanya yang mencakup strategi, pengetahuan, dan keterampilan yang dimiliki. Kreativitas merupakan hasil dari proses berpikir untuk menghasilkan ide baru ataupun hasil kreasi yang telah ada dengan mengkombinasikan unsur-unsur sebelumnya. Proses berpikir ini selalu mengarah pada tingkat inteligensi atau kecerdasan seseorang. Dalam kegiatan pembelajaran matematika, kreativitas yang dimiliki oleh siswa dapat menentukan cara ia menanggapi dan menyelesaikan masalah matematika sehingga dapat disimpulkan siswa yang memiliki kreativitas yang tinggi maka kemampuan pemecahan masalah matematika juga tinggi.

Tabel 10. Hasil Uji Korelasi Kreativitas Terhadap Kemampuan Pemecahan Masalah Matematika

\begin{tabular}{ccccc}
\hline \multicolumn{4}{c}{ Model Summary } \\
\hline Model & $\mathrm{R}$ & $\begin{array}{c}\mathrm{R} \\
\text { Square }\end{array}$ & $\begin{array}{c}\text { Adjusted } \\
\text { R Square }\end{array}$ & $\begin{array}{c}\text { Std. Error } \\
\text { of the } \\
\text { Estimate }\end{array}$ \\
\hline 1 & $.621^{\mathrm{a}}$ & .386 & .375 & 5.759 \\
\hline \multicolumn{4}{c}{ a. } & Predictors: (Constant), Kreativitas \\
\hline
\end{tabular}

Dari tabel tersebut di peroleh besar hubungan kreativitas terhadap kemampuan pemecahan masalah matematika adalah 0,621 , hal ini menunjukkan pengaruh yang sedang. Sedangkan koefisien determinasi sebesar 38,6\% menunjukkan bahwa besarnya kontribusi kreativitas terhadap kemampuan pemecahan masalah matematika adalah sebesar $38,6 \%$, sisanya $(61,4 \%)$ karena pengaruh faktor lain.

\section{Hipotesis 3}

$$
\begin{aligned}
& \mathrm{H}_{0}: \beta_{2}=0 \\
& \mathrm{H}_{1}: \beta_{2} \neq 0
\end{aligned}
$$

Keterangan : 
$H_{o}$ : Tidak terdapat pengaruh kecerdasan emosional terhadap kemampuan pemecahan masalah matematika,

$H_{1}$ : Terdapat pengaruh kecerdasan emosional terhadap kemampuan pemecahan masalah matematika.

Tabel 11. Hasil Uji Koefisien Regresi

\begin{tabular}{rrrrrrr}
\hline \multicolumn{6}{c}{ ANOVA $^{\mathrm{b}}$} \\
\hline & Sum of & Mean & & \\
& Model & Squares & df & Square & F & Sig. \\
\hline 1 & Regression & 505.324 & 1 & 505.324 & 11.2 & $.001^{\text {a }}$ \\
& & & & 33 & \\
\cline { 2 - 7 } & Residual & 2519.29 & 56 & 44.987 & & \\
& 7 & & & & \\
\hline & Total & 3024.62 & 57 & & & \\
& 1 & & & & \\
\hline
\end{tabular}

a. Predictors: (Constant), Kecerdasan_Emosional b. Dependent Variable: KPMM

Tabel tersebut menunjukkan koefisien regresi signifikan karena diperoleh harga $F_{\text {hitung }}=35,182$ dan nilai signifikansi 0,000 $<0,05$ artinya ada pengaruh positif kecerdasan emosi terhadap kemampuan pemecahan masalah matematika.

Kemampuan pemecahan masalah matematika adalah kemampuan seseorang untuk memecahkan masalah matematika dengan menggunakan proses berpikir matematikanya yang mencakup strategi, pengetahuan, dan keterampilan yang dimiliki. Kecerdasan emosional adalah kemampuan seseorang mengenali emosi diri, mengelola emosi, memotivasi diri sendiri dalam membina hubungan dengan orang lain dan berhasil mengatasi tuntutan serta tekanan lingkungan. Siswa yang memiliki kecerdasan emosional yang tinggi maka kemampuan pemecahan masalah matematika juga tinggi. Hal ini di perkuat oleh Hosnan (2016: 204) yang berpendapat bahwa anak yang memiliki kecerdasan emosional tinggi adalah anakanak yang bahagia, percaya diri, dan akan lebih sukses.

Tabel 12. Hasil Uji Korelasi Kecerdasan Emosional Terhadap Kemampuan Pemecahan Masalah Matematika Model Summary

\begin{tabular}{ccccc}
\hline Model & $\mathrm{R}$ & $\begin{array}{c}\mathrm{R} \\
\text { Square }\end{array}$ & $\begin{array}{c}\text { Adjusted R } \\
\text { Square }\end{array}$ & $\begin{array}{c}\text { Std. Error } \\
\text { of the } \\
\text { Estimate }\end{array}$ \\
\hline 1 & $.409^{\mathrm{a}}$ & .167 & .152 & 6.707 \\
\hline \multicolumn{4}{c}{ a. Predictors: (Constant), } \\
Kecerdasan_Emosional \\
\hline
\end{tabular}

Dari tabel tersebut di peroleh besar hubungan kecerdasan emosional terhadap kemampuan pemecahan masalah matematika adalah 0,409 , hal ini menunjukkan pengaruh yang rendah. Sedangkan koefisien determinasi sebesar $16,7 \%$ menunjukkan bahwa besarnya kontribusi kecerdasan emosional secara bersama-sama terhadap kemampuan pemecahan masalah matematika adalah sebesar $16,7 \%$, sisanya $(83,3 \%)$ karena pengaruh faktor lain.

\section{Simpulan dan Saran}

Berdasarkan hasil perhitungan serta analisis penelitian yang sudah dipaparkan sebelumnya, maka dapat disimpulkan: (1) terdapat pengaruh kreativitas dan kecerdasan emosional secara bersamasama terhadap kemampuan pemecahan masalah matematika. (2) terdapat pengaruh 
Kemampuan Pemecahan Masalah Matematika Ditinjau dari Kreativitas dan Kecerdasan Emosional

kreativitas terhadap kemampuan

pemecahan masalah matematika.

terdapat pengaruh kecerdasan emosional terhadap kemampuan pemecahan masalah matematika. Siswa yang memiliki kreativitas dan kecerdasan emosional yang tinggi, maka kemampuan dalam pemecahan masalah matematika juga akan tinggi. Untuk itu, guru diharapkan dapat memberikan inovasi dalam kegiatan pembelajaran, motivasi kepada siswa, melibatkan siswa secara aktif agar dapat menggali ide-ide, gagasan dan melatih kreativitas siswa dalam memecahkan masalah matematika. Guru juga dapat memberikan soal-soal pemecahan masalah yang variatif, bukan hanya sekedar menggunakan rumus dan hapalan yang secara tidak langsung juga melatih kecerdasan emosional siswa agar dapat sabar dan teliti dalam memecahkan masalah matematika.

\section{Daftar Pustaka}

Arikunto, S. (2013). Prosedur Penelitian Suatu Pendekatan Praktik. Jakarta: Rineka Cipta.

Goleman, D. (2015). Emotional Intelligence (Kecerdasan Emosional). Terj. T. Hermaya. Jakarta: Gramedia Pustaka Utama.

Hasbullah \& Wiratomo, Y. (2015). Metode, Model, dan Pengembangan Model Pembelajaran Matematika. Jakarta : Unindra Press
Hosnan, M. (2016). Psikologi Perkembangan Peserta Didik. Bogor: Ghalia Indonesia.

Isvina; Yuan, W; Sugiarti, S; dan Kurniati, D. (2015). Proses Berpikir Kreatif dalam memecahkan masalah Sub Pokok Bahasan Trapesium Berdasarkan Tahapan Wallas Ditinjau dari Adversity Quotient (AQ) Siswa Kelas VII-C SMP Negeri 1 Jember. Artikel Ilmiah Mahasiswa, Vol. 1, No. 1, hal: 1-7.

Mawaddah, S. dan Anisah, H. (2015). Kemampuan Pemecahan Masalah Matematis Siswa Pada Pembelajaran Matematika dengan Menggunakan Model Pembelajaran Generatif. Jurnal Pendidikan Matematika, Vol. 3, No. 2, hal: 166175.

Mubayidh, M. (2006). Ad-Dzaka'Al-Athifi wa Ash-Shihhah Al-Athifiyah (Kecerdasan \& Kesehatan Emosional Anak) Terj. Muh. Muchson Anasy. Jakarta: Pustaka Al-Kautsar.

Lestari, w. 2017. Pengaruh Kemampuan Awal Matematika dan Motivasi Belajar Terhadap Hasil Belajar Matematika. Tersedia [online] http://journal.uinsgd.ac.id/index.php/analisa /article/view/1499/1053

Sianipar; Valentina, K; dan Siagian, R.E.F. 2015. Peningkatan Kemampuan Pemecahan Masalah Matematika Melalui Model Pembelajaran Problem Based Learning (PBL). Prosiding Seminar Nasional Pendidikan Matematika, FTMIPA Universitas Indraprasta PGRI, hal: 165-170. 